\title{
UJI POTENSI BIOHERBISIDA EKSTRAK DAUN MAHONI (Swietenia mahagoni (L.) Jacq) TERHADAP PERTUMBUHAN GULMA MAMAN UNGU (Cleome rutidosperma D.C.)
}

\author{
Agung Kurniawan $^{1 *}$, Yulianty ${ }^{2}$, Endang Nurcahyani ${ }^{3}$ \\ ${ }^{1,2,3}$ Jurusan Biologi FMIPA, Universitas Lampung, Indonesia \\ "E-mail: kuzuryu.smanbi@gmail.com
}

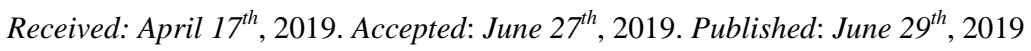

\begin{abstract}
This study aims to test the extract of mahogany leaf (Swietenia mahagoni (L.) Jacq.) against maman ungu weed (Cleome rutidosperma D.C.). The research used RAL (Complete Random Design) with concentration 0\%, 10\%, 20\%, 30\%, 40\%, 50\%, and 60\% with 4 replications. The variables in this study were plant height, wet weight, number of leaves, chlorophyll content $a$, chlorophyll content $b$, and total chlorophyll content. Homogeneity test was using Bartlett test, then analyzed using ANOVA (Analysis of Variance) statistic at 5\% $(p<0,05)$ if there is real difference followed by BNT test at $5 \%$ real level. The results showed extract of mahogany leaves with a concentration of $10 \%$ effective to inhibit the growth of height and number of leaves, while the concentration of $20 \%$ inhibit wet weight of maman ungu weeds.The higher the concentration used, the more effective the mahogany leaf extract is to inhibit the growth of maman ungu weeds. The extract of mahogany leaves has not affected the maman ungu weeds chlorophyll content.
\end{abstract}

Keywords: Bioherbicide, Weeds, Swietenia mahagoni (L.) Jacq., Cleome rutidosperma D.C.)

\begin{abstract}
Abstrak
Penelitian ini bertujuan untuk menguji ekstrak daun mahoni (Swietenia mahagoni (L.) Jacq.) terhadap pertumbuhan gulma maman ungu (Cleome rutidosperma D.C.). Penelitian menggunakan metode RAL (Rancangan Acak Lengkap) dengan konsentrasi 0\%, 10\%, 20\%, $30 \%, 40 \%, 50 \%$, dan 60\% dengan ulangan sebanyak 4 kali. Variabel dalam penelitian ini adalah tinggi tanaman, berat basah, jumlah helai daun, kandungan klorofil a, kandungan klorofil b, dan kandungan klorofil total. Uji homogenitas dilakukan menggunakan uji Bartlett, selanjutnya dianalisis menggunakan metode statistik ANOVA (Analysis of Variance) pada taraf nyata $5 \%(\mathrm{p}<0,05)$ jika terdapat beda nyata dilanjutkan dengan uji BNT pada taraf nyata 5\%. Hasil penelitian menunjukkan ekstrak daun mahoni dengan konsentrasi $10 \%$ efektif untuk menghambat pertumbuhan tinggi dan jumlah helai daun, sedangkan konsentrasi $20 \%$ efektif untuk menghambat berat basah gulma maman ungu. Semakin tinggi konsentrasi yang digunakan maka semakin efektif ekstrak daun mahoni untuk menghambat pertumbuhan gulma maman ungu. Ekstrak daun mahoni belum mempengaruhi kadar klorofil gulma maman ungu.
\end{abstract}

Kata Kunci: Bioherbisida, Gulma, Swietenia mahagoni (L.) Jacq., Cleome rutidosperma D.C. 


\section{PENDAHULUAN}

Gulma merupakan tanaman yang tidak dikehendaki keberadaannya. Gulma dapat menyebabkan kompetisi air, unsur hara, sinar matahari, dan ruang tumbuh yang dapat merugikan tanaman budidaya (pranasari, 2012). Besarnya pengaruh kompetisi gulma ditentukan oleh kesuburan tanah, jenis gulma, jenis tanaman budidaya, kelembaban tanah, pupuk, dan populasi (Madkar, Kuntohartono, \& S. Mangoensoekardjo, 1986). Jika dibandingkan dengan pengendalian hama, pengendalian gulma masih terbilang kurang diperhatikan. Namun, menurut Madkar et al., (1986) akibat yang ditimbulkan oleh gulma dapat menurunkan hasil tanaman padi sebesar 20\%40\% apabila tidak ditanggulangi. Pengendalian gulma yang digunakan di lahan pertanian atau perkebunan saat ini menggunakan teknik mekanik, kultur teknik dan kimiawi yang dinilai kurang efektif dalam pengendalian gulma bahkan beresiko meracuni tanaman (Pebriani, Linda, \& Mukarlina, 2013). Sehingga dapat memunculkan permasalahan yang harus segera dicari cara alternatif untuk menyelesaikanya (Novitasari, Anggoro, Dwi, \& Komarudin, 2019)

Salah satu alternatif usaha pengendalian gulma yang aman adalah dengan menggunakan bioherbisida. Bioherbisida adalah senyawa yang berasal dari organisme hidup, yang mampu mengendalikan gulma atau tanaman pengganggu (Senjaya \& Wahyu Surakusumah, 2008). Teknik pengendalian gulma dengan bioherbisida dapat dilakukan karena adanya senyawa alelokimia yang terkandung di dalam organ tumbuhan. Menurut Muhammad Syakir, Bintoro, Agusta, \& Hermanto, (2008), senyawa alelokimia dapat menghambat pertumbuhan dan perkembangan tanaman lain dengan sifat lebih ramah lingkungan.

Swietenia mahagoni mengandung alkaloid, tanin, saponin, flavanoid, dan teasrpenoid. Menurut Prawinata W.S, Haran, \& P, (1981) senyawa terpenoid, flavonoid dan fenol adalah alelokimia yang bersifat menghambat pembelahan sel. Penelitian yang dilakukan oleh Pebriani et al. (2013) menunjukkan konsentrasi 30\% ekstrak daun M. micrantha yang mampu menghambat perkecambahan serta pertumbuhan gulma maman ungu (Cleome rutidosperma D.C) dan rumput bahia (Paspalum notatum Flugge).

Perbedaan sekaligus pembaharuan dibandingkan penelitian yang lain yaitu mengenai penghambatan pertumbuhan gulma yang terletak pada ekstrak yang digunakan dalam penelitian ini. Penelitian ini menggunakan bioherbisida ekstrak daun mahoni (Swietenia mahagoni (L.) Jacq.) terhadap pertumbuhan gulma maman ungu (Cleome rutidosperma D.C.). Adapun penelitian ini bertujuan untuk menguji ekstrak daun mahoni (Swietenia mahagoni (L.) Jacq.) terhadap pertumbuhan gulma maman ungu (Cleome rutidosperma D.C.).

\section{METODE}

Penelitian ini dilaksanakan di Laboratorium Botani Jurusan Biologi Fakultas Matematika dan Ilmu Pengetahuan Alam dan Laboratorium Lapang Terpadu Fakultas Pertanian Universitas Lampung. Penelitian ini menggunakan bahan berupa biji maman ungu (Cleome rutidosperma D.C.) yang digunakan sebagai tanaman yang akan diuji dan daun mahoni (Swietenia mahagoni (L.) Jacq.) yang digunakan sebagai ekstrak berpotensi bioherbisida. Selain itu juga aquades yang digunakan sebagai kontrol, etanol $96 \%$ sebagai pelarut, tanah beserta pupuk kandang sebagai media. Penelitian ini menggunakan peralatan berupa labu erlenmeyer, pipet, gelas ukur, timbangan analitik, penggaris, schuller, kertas saring, polybag, pisau, oven, plastik, bak tanam, corong buchner dan kertas label. Penelitian ini menggunakan Rancangan Acak Lengkap (RAL) dengan perlakuan konsentrasi ekstrak daun mahoni (Swietenia mahagoni (L.) Jacq.), yaitu 0\%, 10\%, 20\%, 30\%, 40\% $50 \%$, dan $60 \%$ dengan ulangan sebanyak 4 kali. 


\section{Prosedur Kerja}

Pengambilan Sampel, daun diambil sebanyak $5 \mathrm{~kg}$, daun dicuci dengan air hingga bersih, kemudian dikeringanginkan selama 4 hari. Daun yang sudah kering digiling dengan schuller sampai menjadi bubuk sehingga diperoleh berat kering (Nursal, 2006).

Ekstraksi daun Mahoni, ekstraksi daun mahoni menggunakan metode maeserasi. Simplisia daun mahoni direndam dengan etanol 96\% sebanyak 7 liter selama 4 x 24 jam dan dilakukan pengadukan setiap hari. Hasil maserasi disaring dengan kertas saring. Selanjutnya hasil ekstraksi diuapkan dengan menggunakan Rotary evaporator pada suhu $48^{\circ} \mathrm{C}$ dengan kecepatan $90 \mathrm{rpm}$ sampai semua etanol menguap sehingga diperoleh ekstrak mahoni. (Olayele, 2007). Selanjutnya Ekstrak diencerkan menjadi konsentrasi 10\%, 20\%, 30\%, 40\%, 50\%, dan 60\%.

Penanaman, biji maman ungu yang sudah disemaikan sebanyak 100 biji selama 15 hari di pilih 1 gulma yang memiliki tinggi yang sama, kemudian dipindahkan dari bak penyemaian ke dalam 28 buah polybag ukuran $3 \mathrm{~kg}$. Setelah itu penyiraman dengan menggunakan ekstrak daun mahoni sebanyak $5 \mathrm{ml}$ dilakukan pada hari hari ke-20 dan hari ke-30. Penyiraman dilakukan pada tajuk gulma. Pengamatan dihentikan pada hari ke-40 (Gani dkk, 2017).

Parameter Pengamatan, Parameter pertumbuhan Cleome rutidosperma yang di amati adalah tinggi tanaman, berat basah, jumlah daun, dan kandungan klorofil.

\section{HASIL DAN PEMBAHASAN}

Setelah dilaksanakan penelitian pada Hari Setelah Semai (HSS). Diperoleh data rata-rata tinggi gulma maman ungu (Cleome rutidosperma D.C).

Tabel 1. Rata-rata Tinggi Gulma Maman Ungu Setelah Diberikan Ekstrak Daun Mahoni (Swietenia mahagoni ) pada Hari Setelah Semai (HSS).

\begin{tabular}{|c|c|c|c|c|c|c|}
\hline Konsentrasi & $24 \mathrm{HSS}$ & $28 \mathrm{HSS}$ & & $32 \mathrm{HSS}$ & 36 HSS & $40 \mathrm{HSS}$ \\
\hline \multirow[t]{2}{*}{$0 \%$} & $3,05 \pm$ & $4,6 \pm$ & & $9,475 \pm$ & $16,525 \pm$ & $29,55 \pm$ \\
\hline & $0,73 \mathrm{a}$ & $0,829 \mathrm{a}$ & & $2,323 \mathrm{a}$ & $2,818 \mathrm{a}$ & $6.148 \mathrm{a}$ \\
\hline \multirow[t]{2}{*}{$10 \%$} & $2,1 \pm$ & $3,375 \pm$ & & $7,45 \pm$ & $11,75 \pm$ & $21,625 \pm$ \\
\hline & $0,476 \mathrm{~b} \mathrm{c}$ & $0,961 \mathrm{~b}$ & & $1,764 \mathrm{ab}$ & $2,69 \mathrm{~b}$ & $3,713 \mathrm{~b}$ \\
\hline \multirow[t]{2}{*}{$20 \%$} & $2,2 \pm$ & $3,375 \pm$ & & $6,575 \pm$ & $9,275 \pm$ & $18,15 \pm$ \\
\hline & $0,294 \mathrm{~b}$ & $0,299 \mathrm{~b}$ & & $1,632 \mathrm{bc}$ & $0,918 \mathrm{~b}$ & $3,372 \mathrm{~b}$ \\
\hline \multirow[t]{2}{*}{$30 \%$} & $2,1 \pm$ & 2,85 & \pm & $5,575 \pm$ & $8,425 \pm$ & $12,7 \pm$ \\
\hline & $0,183 \mathrm{~b} \mathrm{c}$ & $0,545 \mathrm{~b}$ & & $1,445 \mathrm{~b} \mathrm{c}$ & $2,824 \mathrm{c}$ & $3,621 \mathrm{c}$ \\
\hline \multirow[t]{2}{*}{$40 \%$} & $1,75 \pm$ & 2,825 & \pm & $5,375 \pm$ & $7,2 \pm$ & $10,125 \pm$ \\
\hline & $0,476 \mathrm{c} \mathrm{d}$ & $0,395 \mathrm{~b}$ & & $0,854 \mathrm{~b} \mathrm{c}$ & $1,954 \mathrm{c} \mathrm{d}$ & $2,737 \mathrm{c} \mathrm{d}$ \\
\hline \multirow[t]{2}{*}{$50 \%$} & $1,45 \pm$ & $2,55 \pm$ & & $4,5 \pm$ & $5,3 \pm$ & $8,15 \pm$ \\
\hline & $0,1 \mathrm{~d} \mathrm{e}$ & $0,3 \mathrm{~b}$ & & $0,594 \mathrm{c} \mathrm{d}$ & $0,542 \mathrm{de}$ & $1,806 \mathrm{c} \mathrm{d}$ \\
\hline \multirow[t]{2}{*}{$60 \%$} & $1,225 \pm$ & $1,6 \pm$ & & $2,433 \pm$ & $3,567 \pm$ & $5,233 \pm$ \\
\hline & $0,15 \mathrm{e}$ & $0,265 \mathrm{c}$ & & $0,231 \mathrm{~d}$ & $0,404 \mathrm{e}$ & $0,208 \mathrm{~d}$ \\
\hline
\end{tabular}

Keterangan: angka yang diikuti huruf yang sama pada kolom yang sama menunjukkan tidak berbeda nyata berdasarkan hasil analisis ragam dan uji BNT pada taraf $5 \%$.

Berdasarkan hasil analisis ragam (ANOVA) menunjukkan terdapat pengaruh nyata ekstrak etanol daun mahoni terhadap tinggi gulma maman ungu. Rerata pertumbuhan tinggi maman ungu dapat dilihat pada tabel 1 .

Tinggi gulma maman ungu yang tidak diberikan ekstrak daun mahoni (Konsentrasi 0\%) menunjukkan perbedaan yang nyata dengan konsentrasi $10 \%, 20 \%, 30 \%, 40 \%, 50 \%$, dan $60 \%$. Perbedaan ini terlihat baik pada hari ke-24, ke-28, ke-32, ke- 36, dan ke-40 setelah semai. Tinggi 
tumbuhan yang paling rendah terdapat pada konsentrasi $60 \%$, baik pada tiap hari pengamatan. Hal ini membuktikan bahwa perlakuan yang paling efektif untuk menghambat pertumbuhan maman ungu terdapat pada konsentrasi $60 \%$.

Hasil analisis ragam (ANOVA) berat basah menunjukkan ekstrak etanol daun mahoni memberikan pengaruh terhadap berat basah gulma maman ungu. Rata-rata berat basah maman ungu akan disajikan dalam bentuk Tabel 2 sebagai berikut.

Tabel 2. Rata-rata Berat Basah Gulma Maman Ungu Setelah Diberikan Ekstrak Daun Mahoni (Swietenia mahagoni).

\begin{tabular}{cc}
\hline Konsentrasi & Berat Basah \\
\hline $0 \%$ & $20,141 \pm 3,993 \mathrm{a}$ \\
$10 \%$ & $19,762 \pm 2,464 \mathrm{a}$ \\
$20 \%$ & $15,582 \pm 3,595 \mathrm{a} \mathrm{b}$ \\
$30 \%$ & $11,758 \pm 3,207 \mathrm{~b} \mathrm{c}$ \\
$40 \%$ & $8,966 \pm 3,717 \mathrm{c} \mathrm{d}$ \\
$50 \%$ & $6,883 \pm 3,166 \mathrm{~d} \mathrm{e}$ \\
$60 \%$ & $2,138 \pm 0,318 \mathrm{e}$
\end{tabular}

Keterangan: angka yang diikuti huruf yang sama pada kolom yang sama menunjukkan tidak berbeda nyata berdasarkan hasil analisis ragam dan uji BNT pada taraf 5\%

Tabel 2 di atas terlihat perlakuan ekstrak daun mahoni konsentrasi $0 \%$ tidak berbeda nyata dengan perlakuan konsentrasi $10 \%$ dan $20 \%$, tetapi berbeda nyata dengan konsentrasi yang lain. Konsentrasi 50\% tidak berbeda nyata dengan konsentrasi $60 \%$. Berat basah terendah terdapat pada konsentrasi $60 \%$. Hal ini menunjukkan konsentrasi yang efektif dalam menghambat berat basah terdapat pada konsentrasi $60 \%$.

Hasil analisis ragam (ANOVA) Jumlah helai daun menunjukkan ekstrak etanol daun mahoni memberikan pengaruh terhadap pertumbuhan rata-rata jumlah helai daun pada gulma maman ungu. Untuk lebih jelasnya akan disajikan dalam bentuk Tabel 3 sebagai berikut.

Tabel 3. Rata-rata Jumlah Helai Daun Gulma Maman Ungu Setelah Diberikan Ekstrak Daun Mahoni (Swietenia mahagoni)

\begin{tabular}{cc}
\hline Konsentrasi & Jumlah Helai Daun \\
\hline $0 \%$ & $159 \pm 46,93 \mathrm{a}$ \\
$10 \%$ & $111 \pm 14,28 \mathrm{a} \mathrm{b}$ \\
$20 \%$ & $106,5 \pm 27,67 \mathrm{~b} \mathrm{c}$ \\
$30 \%$ & $79 \pm 44.98 \mathrm{~b} \mathrm{c} \mathrm{d}$ \\
$40 \%$ & $58 \pm 43,43 \mathrm{c} \mathrm{d}$ \\
$50 \%$ & $56 \pm 18,97 \mathrm{~d}$ \\
$60 \%$ & $29,33 \pm 10,41 \mathrm{~d}$
\end{tabular}

Keterangan: angka yang diikuti huruf yang sama pada kolom yang sama menunjukkan tidak berbeda nyata berdasarkan hasil analisis ragam dan uji BNT pada taraf 5\%

Tabel 3 di atas menunjukkan konsentrasi $0 \%$ (kontrol) tidak berbeda nyata dengan konsentrasi $10 \%$, tetapi berbeda nyata dengan konsentrasi $20 \%, 30 \%$, 40\%, 50\%, dan $60 \%$. Jumlah 
helai daun yang paling kecil terdapat pada konsentrasi $60 \%$. Konsentrasi yang efektif untuk menghambat jumlah helai daun adalah $60 \%$.

Kandungan klorofil yang di uji meliputi klorofil a, klorofil b, dan klorofil total. Dari uji ANOVA $(0,05)$ untuk kandungan klorofil a, klorofil $b$ dan klorofil total, diketahui bahwa pemberian ekstrak daun mahoni tidak berpengaruh nyata terhadap kandungan klorofil a, klorofil $b$, dan klorofil total gulma maman ungu. Rata-rata kandungan klorofil a, klorofil b, dan klorofil total dapat dilihat dalam tabel 4 sebagai berikut.

Tabel 4. Rata-rata Kandungan Klorofil Gulma Maman Ungu Setelah Diberikan Ekstrak Daun Mahoni (Swietenia mahagoni)

\begin{tabular}{cccc}
\hline Konsentrasi & Klorofil a & Klorofil b & Klorofil Total \\
\hline $0 \%$ & $2,000 \pm 0,248$ & $1,201 \pm 0,118$ & $0,892 \pm 0,087$ \\
$10 \%$ & $2,181 \pm 0,331$ & $1,349 \pm 0,160$ & $1,003 \pm 0,118$ \\
$20 \%$ & $1,806 \pm 0,126$ & $1,234 \pm 0,088$ & $0,921 \pm 0,066$ \\
$30 \%$ & $1,775 \pm 0,463$ & $1,170 \pm 0,183$ & $0,871 \pm 0,133$ \\
$40 \%$ & $1,331 \pm 0,231$ & $1,006 \pm 0,144$ & $0,753 \pm 0,107$ \\
$50 \%$ & $1,907 \pm 0,262$ & $1,233 \pm 0,086$ & $0,918 \pm 0,062$ \\
$60 \%$ & $1,784 \pm 0,551$ & $1,169 \pm 0,302$ & $0,871 \pm 0,223$
\end{tabular}

Keterangan: angka yang diikuti huruf yang sama pada kolom yang sama menunjukkan tidak berbeda nyata berdasarkan hasil analisis ragam (ANOVA)

\section{Tinggi Tanaman}

Berdasarkan hasil penelitian, ekstrak daun mahoni berpengaruh terhadap pertumbuhan tinggi gulma maman ungu. Konsentrasi yang efektif untuk mempengaruhi pertumbuhan maman ungu adalah dengan pemberian ekstrak 10\%. Semakin tinggi konsentrasi yang diberikan maka semakin efektif untuk menghambat pertumbuhan tinggi gulma maman ungu.

Tinggi tanaman merupakan ukuran tanaman yang mudah untuk diamati dan sering digunakan sebagai parameter untuk mengukur pengaruh dari lingkungan atau pemberian perlakuan. Tinggi tanaman dapat dipengaruhi oleh air atau pun senyawa lainnya. Ekstrak etanol daun mahoni (Swietenia mahagoni) mengandung alkaloid, tanin, saponin, flavanoid, dan terpenoid (Amelia, 2015). Salah satu senyawa metabolit sekunder yang diduga sebagai bioherbisida adalah tanin yang termasuk kelompok senyawa fenolik. Menurut Marisa (1990) tanin dapat menghambat pertumbuhan, mengganggu proses respirasi pada mitokondria serta mengganggu transport ion $\mathrm{Ca}^{+2}$ dan $\mathrm{PO}^{3-}$. Selain itu senyawa tanin juga dapat menonaktifkan enzim amilase, protease, lipase, urease, dan dapat menghambat aktivitas hormon giberelin. Selain tanin, senyawa metabolit sekunder yang diduga sebagai bioherbisida adalah flavonoid. Menurut Khotib (2002) Flavonoid berperan dalam proses penghambatan pertumbuhan, yaitu berperan sebagai penghambat kuat terhadap IAA-oksidase.

Senyawa metabolit sekunder yang digunakan sebagai bioherbisida dapat menghambat dan mengurangi hasil pada proses-proses utama tumbuhan. Hambatan tersebut misalnya terjadi pada pembentukan asam nukleat, protein, dan ATP. Jumlah ATP yang berkurang dapat menekan hampir seluruh proses metabolisme sel, sehingga sintesis zat-zat lain yang dibutuhkan oleh tumbuhan pun akan berkurang (Salisbury \& Ross, 1992). Menurut Yuliani (2000) masuknya senyawa metabolit sekunder yang digunakan sebagai bioherbisida bersama air ke dalam biji akan menghambat induksi hormon pertumbuhan seperti asam giberelin (GA) dan asam indolasetat (IAA). Dengan dihambatnya sintesis giberelin maka tidak akan terjadi pemacuan enzim $\alpha$-amilase, sehingga proses hidrolisis pati menjadi glukosa di dalam endosperma atau kotiledon berkurang. Kemudian jumlah 
glukosa yang dapat dikirim ke titik-titik tumbuh lebih sedikit (Rice, 1984). Berkurangnya komponen makromolekul mengakibatkan terhambatnya sintesis protein yang juga akan berakibat pada terhambatnya sintesis protoplasma. Oleh karena itu proses pembelahan dan pemanjangan sel akan terhambat, yang kemudian berakibat pada terhambatnya proses perkecambahan dan pertumbuhan (yuliani, 2000).

\section{Berat Basah}

Berdasarkan hasil penelitian, terdapat perbedaan yang signifikan yang terlihat mulai pemberian ekstrak 0\% hingga 60\%. Pada tiap tahapan tingkat pemberian konsentrasi ektrak daun mahoni memberikan hasil yang efektif untuk menghambat pertambahan berat basah pada gulma maman ungu. Pemberian ekstrak daun mahoni pada konsentrasi $10 \%$ memberikan hasil yang efektif terhadap berat basah gulma maman ungu. Semakin tinggi konsentrasi yang diberikan maka semakin efektif untuk menghambat berat basah gulma maman ungu.

Berat basah tanaman adalah berat tanaman pada saat masih hidup dan ditimbang langsung sebelum tanaman menjadi layu karena kehilangan air (Lakitan, 1996). Berat basah tanaman merupakan parameter untuk mengetahui biomasa dari pertumbuhan tumbuhan maman ungu. Biomassa tanaman merupakan suatu ukuran hasil dari pertumbuhan tanaman yang dihasilkan dari reaksi - reaksi biokimia yang diawali dari penyusunan sel - sel yang akan membentuk jaringan kemudian akan membangun organ hingga pada akhirnya membentuk suatu tumbuhan. Tingginya berat basah tumbuhan dipengaruhi oleh kandungan air dalam tumbuhan tersebut. Biomassa tanaman meliputi semua bahan tanaman yang, secara kasar, berasal dari hasil fotosintesis, serapan unsur hara dan air yang diolah melalui proses biosintesis (Sitompul \& Bambang Guritno, 1995). Pengaruh ekstrak daun mahoni terhadap berat basah maman ungu dikarenakan alelokimia dapat menghambat proses penyerapan air. Alelokimia dapat menghambat permeabilitas membran sel (Farooq, Bajwa, Cheema, \& Cheema, 2013). Dimana membran sel adalah jalan untuk keluar masuknya air.

\section{Jumlah helai daun}

Jumlah helai daun gulma maman ungu didapatkan hasil yang signifikan. Pada tiap tahapan tingkat pemberian konsentrasi ektrak daun mahoni memberikan hasil yang efektif untuk menghambat pertumbuhan jumlah helai daun pada gulma maman ungu. Pemberian ekstrak daun mahoni dengan pada 20\% telah memberikan hasil efektif terhadap pertumbuhan jumlah helai daun gulma maman ungu. Semakin tinggi konsentrasi yang diberikan maka semakin efektif untuk menghambat pertumbuhan jumlah helai daun maman ungu.

Alelokimia pada ekstrak daun mahoni dapat mempengaruhi fungsi fisiologis tumbuhan. Menurut Omezzine, Haouala \& Ladhari (2014) alelokimia dapat mengganggu penyerapan unsur hara pada akar, fotosintesis, respirasi, dan transpirasi. Terganggunya proses fotosintesis, respirasi, dan transpirasi berdampak pula pada pembentukan jumlah daun. Selain itu alelokimia juga dapat menghambat proses pengangkutan air. Hal ini sesuai dengan pendapat Farooq dkk. (2013) yang mengatakan bahwa pada kondisi normal, membran sel bersifat selektif permeabel, namun akibat dari alelokimia membran sel akan terganggu sehingga tidak bersifat selektif permeabel lagi sehingga mekanisme seluler tidak dapat berjalan dengan baik.

\section{Kandungan Klorofil}

Salah satu indikasi kesuburan tanaman adalah luasnya penampang daun dan banyaknya daun. Salah satu penyusun daun adalah kloroplas. Di dalam kloroplas terdapat pigmen berwarna hijau (klorofil) yang berfingsi dalam proses fotosintesis (Setiari \& Nurchayati, 2009). Hasil fotosintesis digunakan untuk membentuk ATP yang berguna untuk pertumbuhan dan perkembangan sel. Pemberian ekstrak daun mahoni terhadap gulma maman ungu berdasarkan ANOVA $(0,05)$ tidak menunjukan beda nyata terhadap kandungan klorofil. Hal ini menunjukan bahwa ekstrak daun mahoni tidak mempengaruhi pembentukan klorofil. Pembentukan klorofil dipengaruhi oleh faktor genetika, oksigen, karbohidrat, unsur hara, air, suhu, dan cahaya (Dwidjoseputro, 1980). Selain itu, 
kandungan klorofil yang tidak berbeda nyata juga dipengaruhi oleh adanya persamaan penerimaan cahaya. Semakin tinggi intensitas cahaya yang diterima, maka kandungan klorofil akan semakin tinggi (Ginting, Syafrinal, \& Sri Yoseva, 2017). Tidak adanya pengaruh ekstrak daun mahoni terhadap kandungan klorofil a, b, dan total disebabkan karena pemberian ekstrak di atas tidak sampai menimbulkan gejala kerusakan maman ungu. Menurut Isda, \& Fitri, (2013) gejala kerusakan gulma ditandai dengan adanya klorosis dan nekrosis pada daun.

\section{KESIMPULAN}

Berdasarkan hasil penelitian ini, dapat disimpulkan bahwa ekstrak daun mahoni dapat menghambat pertumbuhan tinggi, berat basah, dan jumlah helai daun gulma maman ungu, serta ekstrak daun mahoni tidak mempengaruhi jumlah klorofil gulma maman ungu, sedangkan konsentrasi $10 \%$ efektif untuk menghambat pertumbuhan tinggi, berat basah, dan jumlah helai daun maman ungu. Semakin tinggi konsentrasi yang digunakan maka semakin efektif ekstrak daun mahoni untuk menghambat pertumbuhan gulma maman ungu.

Perlu dilakukan penelitian lebih lanjut menggunakan pelarut selain ethanol contohnya air, serta menambahkan lebih banyak parameter ukur..

\section{DAFTAR PUSTAKA}

Amelia, T. R. N. (2015). Efektivitas Ekstrak Air dan Etanol Daun Mahoni (Swietenia mahagoni (L.) Jacq.) terhadap Larva dan Imago Aedes aegypti. universitas Gajah Mada Jogyakarta.

Dwidjoseputro, D. (1980). Pengantar fisiologi tumbuhan. Jakarta: gramedia.

Farooq, M., Bajwa, A. A., Cheema, S. A., \& Cheema, Z. A. (2013). Application of Allelopathy in Crop Production. Internatioal Journal Of Agriculture \& Biology, 15(6), 1367-1378.

Ginting, R. P., Syafrinal, \& Sri Yoseva. (2017). Pengaruh Beberapa Bahan Aktif Herbisida Pada Sistem Tanam Segitiga Terhadap Pertumbuhan Dan Produksi Tanaman Jagung Manis (Zea mays var. saccharata Sturt.), 4(2), 14-15.

Isda, M. N., Dan, S. F., \& Fitri, R. (2013). Potensi Ekstrak Daun Gulma Babadotan (Ageratum Conyzoides L.) Terhadap Perkecambahan Dan Pertumbuhan Paspalum conjugatum Berg., 6(2), 120-125.

Lakitan, B. (1996). Dasar-Dasar Fisiologi Tumbuhan. Jakarta: PT. Radja. Grafindo Persada.

Madkar, O. R., Kuntohartono, T., \& S. Mangoensoekardjo. (1986). Masalah Gulma dan Cara Pengendalian. Bogor: Himpunan Ilmu Gulma Indonesia.

Marisa, H. (1990). Pengaruh ekstrak daun pinus (Pinus merkusii) terhadap Perkecambahan dan pertumbuhan vegetatif tanaman kedelai (Glycine max (L.) Merr.). Institut Teknologi Bandung.

Muhammad Syakir, Bintoro, M. H., Agusta, H., \& Hermanto. (2008). Pemanfaatan Limbah Sagu Sebagai Pengendalian Gulma. Jurnal Littri, 14(3), 107-112.

Novitasari, C., Anggoro, B. S., Dwi, D., \& Komarudin. (2019). Analisis Sarang Lebah Madu Dalam Geometri Matematika Dan Alquran, 8(1), 146-158.

Omezzine, F., Haouala, R., \& Ladhari, A. (2014). Physiological and Biochemcal mechanisms of 
allelochemicals in aqueous extract of diploid and mixoploid Trigonella foenum-graceum L. South African Journal of Botany, 93, 167-178.

Pebriani1, Linda1, R., \& Mukarlina1. (2013). Potensi Ekstrak Daun Sembung Rambat (Mikania micrantha H.B.K) Sebagai Bioherbisida terhadap Gulma Maman Ungu (Cleome rutidosperma D.C) dan Rumput Bahia (Paspalum notatum Flugge), 2(2), 32-38.

Pranasari. (2012). Pengendalian Gulma dengan Pengaturan Jarak Tanam dan Cara Penyiangan pada Tanaman Kedelai. Prosiding Konferensi Himpunan Ilmu Gulma Indonesia.

Prawinata W.S, Haran, \& P, T. (1981). Dasar-Dasar Fisiologi Tumbuhan. Bogor: Institut Pertanian Bogor.

Rice, E. (1984). Alleopathy. (2nd ed.). london: academic press.

Salisbury, F. B., \& Ross, C. W. (1992). Plant Physiology, Hormones and Plant Regulators: Auxins and Gibberellins (4th ed.). Belmont: Wadsworth Publishing.

Senjaya, Y. A., \& Wahyu Surakusumah. (2008). Potensi Ekstrak Daun Pinus (Pinus merkusii Jungh. et de Vriese) Sebagai Bioherbisida Penghambat Perkecambahan Echinochloa colonum L. dan Amaranthus viridis. Jurnal Parennial, 4(1), 1-5.

Setiari, N., \& Nurchayati, Y. (2009). Eksplorasi Kandungan Klorofil pada beberapa Sayuran Hijau sebagai Alternatif Bahan Dasar Food Supplement, 11(1), 6-10.

Sitompul, S. M., \& Bambang Guritno. (1995). Analisis Pertumbuhan Tanaman. Yogyakarta: Gadjah Mada University Press.

Yuliani. (2000). Pengaruh Alelopati Kamboja (Plumeria acuminata W. T. Ait.) Terhadap Perkecambahan Biji dan Pertumbuhan Kecambah Celosia argentea L. universitas negeri malang. 